\begin{tabular}{|l|l|l||}
\hline \multicolumn{2}{|c|}{ PublisherInfo } \\
\hline \hline PublisherName & $:$ & BioMed Central \\
\hline \hline PublisherLocation & $:$ & London \\
\hline \hline PublisherImprintName & $:$ & BioMed Central \\
\hline \hline
\end{tabular}

\title{
Transgenic and targeted mouse mutation database
}

\begin{tabular}{|l|l|l||}
\hline \multicolumn{2}{|c|}{ ArticleInfo } \\
\hline \hline ArticleID & $:$ & 3935 \\
\hline \hline ArticleDOI & $:$ & $10.1186 /$ gb-2001-2-8-reports2005 \\
\hline \hline ArticleCitationID & $:$ & reports2005 \\
\hline \hline ArticleSequenceNumber & $:$ & 26 \\
\hline \hline ArticleCategory & $:$ & Web report \\
\hline \hline ArticleFirstPage & $:$ & 1 \\
\hline \hline ArticleLastPage & $:$ & 3 \\
\hline \hline & & RegistrationDate : 2001-6-22 \\
ArticleHistory & $:$ & Received \\
& & OnlineDate 2001-6-22 \\
\hline \hline ArticleCopyright & $:$ & BioMed Central Ltd2001-7-20 \\
\hline \hline ArticleGrants & $:$ & \\
\hline \hline
\end{tabular}




\begin{tabular}{|l|l|l|}
\hline ArticleContext & $:$ & 130592288 \\
\hline
\end{tabular}

\section{Steven G Gray}

\section{Abstract}

TBASE is a database of information on all transgenic mice and targeted mutations, with particular emphasis on knockouts.

\section{Content}

TBASE is a database of information on all transgenic mice and targeted mutations, with particular emphasis on knockouts. Since the advent of manipulative techniques for altering the mouse germline, large numbers of transgenic animals have been developed. With an increase in the number of techniques for targeting specific genes using homologous recombination in mouse embryonic stem cells, this has resulted in a large number of mutant lines with specific phenotypes and well-defined DNA-structural changes. The database currently holds 18,428 citation records in the Citation Database, covering publications on both transgenic and knockout strains, 1,614 transgenes or targeting vector descriptions and 3,876 mutant-strain records. Of the latter, approximately 800 records describe transgenic mouse strains; the remaining 3,076 records describe mouse knockouts.

\section{Navigation}

The site contains an extensive search engine, with many options. If you already know the TBASE ID number of your target you can search directly using it, but any researcher should be able to query the database as it has a large number of search options, and operators may be used. The website itself is well laid out and easy to navigate. It includes a well-developed section with detailed instructions on how to initiate searches, and a comprehensive section of links devoted to transgenic and targeted mutation research.

\section{Reporter's comments}

\section{Timeliness}


The last update for the website itself was in January 2001, but the database, especially the Citation Database, is updated weekly.

\section{Best feature}

It is easy to use and frequently updated. This site has several important features, including a welldeveloped search engine with good instructions and a large glossary section. Best of all, you are encouraged to submit your own data if you have developed any transgenic/knockout strains. When I tried to e-mail the coordinator using the TBASE technical support address supplied on the page, I did not receive any response. But a direct e-mail to the person in charge - Anna Anagnostopoulos - was answered promptly and efficiently.

\section{Related websites}

Other useful sites about mouse genetics are Induced mutant resource (IMR) transgenic and targeted mutant mice, JAX mice, European mouse mutant archive, and The mouse atlas and gene expression database project.

\section{Table of links}

TBASE

Induced mutant resource (IMR) transgenic and targeted mutant mice

JAX mice

European mouse mutant archive

The mouse atlas and gene expression database project

\section{References}

1. TBASE. 